\title{
Trace metals in bivalves and seagrass collected from Venezuelan coastal sites
}

\author{
J.A. Alfonso ${ }^{1}$, J. Azocar ${ }^{1}$, J.J. LaBrecque ${ }^{1}$, B. Garcia ${ }^{1}$, D. Palacios ${ }^{2}$ \& Z. Benzo ${ }^{1}$ \\ 1. Instituto Venezolano de Investigaciones Científicas, Apartado 21827, Caracas 1020A, Venezuela; jalfonso@ivic.ve \\ 2. Universidad Simón Bolívar, Apartado 89000, Caracas 1080, Venezuela
}

Received 13-VII-2007. C Corrected 03-I-2008. $\quad$ Accepted 13-II-2008.

\begin{abstract}
The bivalve mollusks Tivela mactroides and Crassostrea rhizophorae are abundant along the Venezuelan coast and are widely consumed as seafood. The globally important seagrass Thalassia testudinum is also abundant in Venezuelan. We report the concentrations of $\mathrm{Cd}, \mathrm{Cr}, \mathrm{Cu}, \mathrm{Ni}, \mathrm{V}$ and $\mathrm{Zn}$ in the soft parts of Tivela mactroides and Thalassia testudinum, and the concentrations of $\mathrm{Cd}, \mathrm{Cr}, \mathrm{Cu}$ and $\mathrm{Ni}$ in the soft parts of Crassostrea rhizophorae, in seven Venezuelan coastal sites. Metal concentrations were determined by Inductively Coupled Plasma Optical Emission Spectroscopy. Statistical analysis (one-way ANOVA) indicated that the organisms had different levels of metal bioaccumulation, and might be used as biomonitors for trace metals. Significant site-specific differences were found for the elements $\mathrm{Cd}, \mathrm{Cr}, \mathrm{Ni}$ and $\mathrm{V}$ in Tivela mactroides; $\mathrm{Cd}$ and $\mathrm{Cr}$ in Crassostrea rhizophorae; and V in Thalassia testudinum tissue. Rev. Biol. Trop. 56 (Suppl. 1): 215-222. Epub 2008 May 30.
\end{abstract}

Key words: metal bioaccumulation, Tivela mactroides, Crassostrea rhizophorae, Thalassia testudinum, bivalves, seagrass.

Bivalves have been extensively used as bio-indicators to assess the environmental conditions of coastal aquatic environments (Liang et al. 2004, Silva et al. 2006), since they can accumulate trace metals and other substances. Tivela mactroides and Crassostrea rhizophorae are two species of bivalves abundant along the Venezuelan coast and widely consumed by local populations. The clam Tivela mactroides has been considered to be a potential biomonitor of trace metals in Venezuelan marine ecosystems (LaBrecque et al. 2004a, Alfonso et al. 2005, Jaffe et al. 1995). It is well known that seagrasses are critical to the structure and function of many marine ecosystems (Klumpp et al. 1989). Seagrasses provide habitat, sediment stability, nutrients, and a food source. The seagrass, Posidonia oceanica, has been studied as a biomarker of trace metal contamination in various parts of the world, especially the Mediterranean coast (Costantini et al. 1991, Catiski and Panayotidis 1993). The globally important seagrass T. testudinum is a climax species (Zieman 1982) very abundant in Venezuelan coastal zones. Along the US Florida coast, Thalassia testudinum leaves were used to evaluate the As content in several estuaries (Fourqurean and Cai 1993). In the Laguna Madre of Texas, several studies of the trace metal content in T. testudinum and Halodule wrightti have been reported (Pulich 1980, Whelan et al. 2005). Only a few studies have been reported on trace metals in bivalves and seagrass from Venezuela, however, such studies have not dealt with bioaccumulation variations in different organisms and have mainly been undertaken in very restricted areas and for a limited number of metals. 
In this work, we report concentrations of $\mathrm{Cd}, \mathrm{Cr}, \mathrm{Cu}, \mathrm{Ni}, \mathrm{V}$ and $\mathrm{Zn}$ in the soft bodies of Tivela mactroides and in the Thalassia testudinum tissue, and of $\mathrm{Cd}, \mathrm{Cr}, \mathrm{Cu}$ and $\mathrm{Ni}$ in the soft bodies of Crassostrea rhizophorae, which were collected at sites along the Venezuelan coast. Seagrass tissue was separated into blades and roots/rhizomes. This dataset is part of an ongoing study to evaluate temporal and spatial variation of potentially toxic metals in bivalves of commercial interest.

\section{MATERIALS AND METHODS}

Study sites: This study was carried-out in sampling seven Venezuelan coastal sites (Fig. 1): Los Pozones (1055’32” N-68¹6’42” W), in Golfete de Cuare, State of Falcon; Boca de Aroa (10 $45^{\prime} 49^{\prime \prime}$ N-68 $19^{\prime} 24^{\prime \prime}$ W), State of Falcon; Isla Buche (10³2’36” N-6605'22”'W), in Carenero, State of Miranda; Playa Chocolate (10²7'48” N-66 04'59' W), in Higuerote, State of Miranda; El Hatillo (1008'34” N-6510'21' W), State of Anzoategui; Pertigalete ( $10^{\circ} 14^{\prime} 38^{\prime \prime}$ N-64'34'35" W), State of Anzoategui and Isla Larga (10²0’28” N-64¹9’56” W), in Mochima, State of Cumana. Each sampling site corresponds to an area of $30-60 \mathrm{~m}^{2}$. Samples of Tivela mactroidea were collected at Boca de
Aroa, Playa Chocolate and El Hatillo, while samples of Crassostrea rhizophorae at Los Pozones, Isla Buche and Isla Larga. Samples of Thalassia testudinum were collected at Isla de Buche, Pertigalete and Isla Larga.

\section{Sampling and sample pretreatment:}

The sampling was carried out between January and February during 2005 and 2006. Samples of Tivela mactroidea and Thalassia testudinum were colleted by hand from the marine sediment, while samples of Crassostrea rhizophorae were collected using a stainless steel knife. It is well known that the accumulation of heavy metals in bivalves is affected by age, size and weight of the mollusk (Rainbow 2000, RuelasInzunza and Paez-Ozuna 2000). As these factors were not the objective of our study, they were kept as constant as possible, in order to minimize their influence on the measured concentrations. Each Tivela mactroidea sample consisted of a group of at least 20 clams 3-4 $\mathrm{cm}$ in size, whereas Crassostrea rhizophorae sample of a group of at least 15 oysters $6-7 \mathrm{~cm}$ in size. Seagrass tissue was separated into leaf blades and roots/rhizomes. Triplicate samples were collected at each sampling site was taken three samples. All samples were rinsed with seawater after collection to remove marine

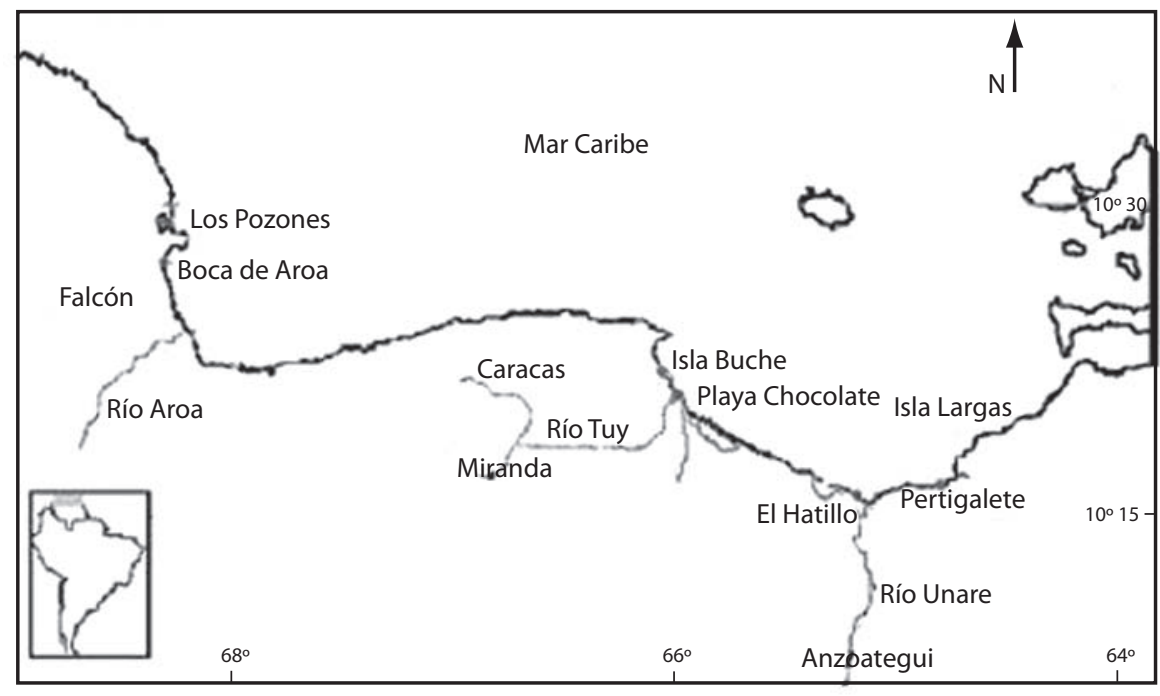

Fig. 1. Sampling sites, states and rivers; Venezuela. 
sediments, shells and other debris, placed in plastic bags and transported to the laboratory on ice.

In the laboratory, the complete soft tissue of mollusks was removed from the shell and washed with distilled deionized water to remove marine sediment and others impurities. The bivalves tissues were transferred to clean one-liter beakers and washed several times with distilled deionized water until the solution was clear. After discarding the excess liquid, the beakers were placed in a drying oven at about $65^{\circ} \mathrm{C}$ until most of the liquid was evaporated, then the temperature was increased to $80^{\circ} \mathrm{C}$ for 24 hours, then cooled in desiccators. Previous studies showed that rinsing seagrasses with distilled water caused premature leaching of metals and other cations (Ledent et al. 1995). Thus, seagrass tissues were blotted with paper towels and set out at room temperature until partially dry in the laboratory. Epiphytes were easily removed from the partially dry leaves by scraping. After partial drying at room temperature, all of the tissue was oven dried at $80^{\circ} \mathrm{C}$ for $24 \mathrm{~h}$ and cooled in desiccators.

The dried tissue samples were ground into a fine powder with an agate mortar and pestle and well mixed to prepare homogenous samples. One gram portions of the dried tissues were dissolved in $8 \mathrm{ml}$ of concentrated super pure nitric acid (Merck) by heating on a hot plate at about $70{ }^{\circ} \mathrm{C}$ for about 8 hours. When the solution cooled, $2 \mathrm{ml}$ of hydrogen peroxide (30\%) (Merck) was added and heated again at $70^{\circ} \mathrm{C}$ for another 4 hours. Finally, the resulting solution was diluted to $50 \mathrm{ml}$ with distilled deionized water. Duplicate digestions were performed for each sample. Method blanks were always low indicating minimal contamination during sample processing, and they were subtracted from sample readings to give final values of metal concentration.

Chemical analysis: The samples were then analysed by Inductively Coupled Plasma Optical Emission Spectroscopy (ICPOES) using a Perkin Elmer, Optima 3000. Determination of $\mathrm{Cd}, \mathrm{Cr}, \mathrm{Cu}, \mathrm{Ni}, \mathrm{V}$ and $\mathrm{Zn}$ was carried out in the automatic mode, with background correction employing the ICPWinLab Optima 3000 software package. The following wavelengths were used: $226.502 \mathrm{~nm}$ for Cd, $205.552 \mathrm{~nm}$ for Cr, $324.754 \mathrm{~nm}$ for $\mathrm{Cu}, 231.604 \mathrm{~nm}$ for $\mathrm{Ni}, 292.402 \mathrm{~nm}$ for $\mathrm{V}$ and $202.548 \mathrm{~nm}$ for $\mathrm{Zn}$. A comparison of the trace metals determination using the above described methodology and reported values for mussel tissue reference materials NIST-2977, NIST-2977 and aquatic plant reference material BCR-60 are presented in Tables 1 and 2. It can

TABLE 1

The comparison of the determined mean and standard deviation values $(n=6)$ in mussel tissue standard reference materials NIST-2976 and NIST-2977 in this study with the certified (CV), recommended (RV) and information (IV) values

Element

NIST-2976

Reference material values ( $\mu \mathrm{g} / \mathrm{g})$

This study

( $\mu \mathrm{g} / \mathrm{g})$

$\begin{array}{cc}\mathrm{Cd} & 0.82 \pm 0.16(\mathrm{CV}) \\ \mathrm{Cr} & 0.50 \pm 0.16(\mathrm{RV}) \\ \mathrm{Cu} & 4.02 \pm 0.33(\mathrm{CV}) \\ \mathrm{Ni} & 0.93 \pm 0.12(\mathrm{RV}) \\ \mathrm{V} & - \\ \mathrm{Zn} & 137 \pm 13(\mathrm{CV})\end{array}$

$<\mathrm{dl}=$ below detection limit.
NIST-2977

Reference material values
( $\mu \mathrm{g} / \mathrm{g})$

This study ( $\mu \mathrm{g} / \mathrm{g})$

$$
\begin{gathered}
0.179 \pm 0.003(\mathrm{CV}) \\
3.91 \pm 0.47(\mathrm{RV}) \\
9.42 \pm 0.52(\mathrm{CV}) \\
6.06 \pm 0.24(\mathrm{CV}) \\
1.1(\mathrm{IV}) \\
135 \pm 5(\mathrm{RV})
\end{gathered}
$$$$
<\mathrm{dl}
$$ 
TABLE 2

The comparison of the determined mean and standard deviation values $(n=6)$ in aquatic plant tissue standard reference material BCR-60 in this study with the certified $(\mathrm{CV})$ values

$\begin{array}{ccc}\text { Element } & \begin{array}{c}\text { BCR-60 } \\ \text { Reference material } \\ \text { values }(\mu \mathrm{g} / \mathrm{g})\end{array} & \begin{array}{c}\text { This study } \\ (\mu \mathrm{g} / \mathrm{g})\end{array} \\ \mathrm{Cd} & 2.20 \pm 0.10(\mathrm{CV}) & 2.17 \pm 0.12 \\ \mathrm{Cu} & 51.2 \pm 1.9(\mathrm{CV}) & 51.3 \pm 1.1 \\ \mathrm{Zn} & 313 \pm 8(\mathrm{CV}) & 311.5 \pm 6.3\end{array}$

be seen that determined values were very similar to the certified and recommended values, thus the method employed (LaBrecque et al. 2004b) can be considered accurate. Standard deviations $(1 \sigma)$ of the element determinations $(n=6)$ are small, indicating good precision. The detection limits were determined as three times the standard deviation of the background under the emission lines of the selected trace elements for the blank solution. The detection limits of $\mathrm{Cd}, \mathrm{Cr}, \mathrm{Cu}, \mathrm{Ni}, \mathrm{V}$ and $\mathrm{Zn}$ were 0.79 , $0.93,0.25,1.1,0.32$ and $0.16 \mu \mathrm{g} / \mathrm{g}$.

Statistical analysis: A one way ANOVA was performed in order to evaluate the statistical significance of variations between the two sampling times and the sites, for each species and the metals considered. A value of $\mathrm{p}<0.05$ was considered to indicate a significant difference. Statistical analyses were carried out using Statistica 6.0 software (StatSoft, USA).

\section{RESULTS}

Results of the one-way ANOVA of comparison between the two sampling times for metal concentrations are presented in Table 3. In all sampling sites, the difference in the mean metal concentrations between the two sampling times was no significant ( $\mathrm{p}>0.05$ ), so a combination of 2005 and 2006 data will be considered.
Mean and standard deviation of the trace metal concentrations in Tivela mactroides, Crassostrea rhizophorae and Thalassia testudinum tissues from the two sampling times are presented in Tables 4, 5 and 6, respectively. Significance levels were fixed at $\mathrm{p}<0.05$ on 95 $\%$ confidence level. For each organism studied, mean values of metals with significant concentration differences between the sampling sites are marked by an asterisk.

\section{DISCUSSION}

The mean concentrations of $\mathrm{Cd}, \mathrm{Cr}$ and $\mathrm{Ni}$ in Tivela mactroides samples were significantly higher in Playa Chocolate. This was not unexpected, considering the fact that this site are located west of the mouth of the Tuy River, which has a plume known to move in a northwesterly direction and receives the waste water effluents from the metropolitan area of Caracas, a city of approximately 6 million inhabitants, via the Guaire River. Most of this waste water undergoes only minor treatment. In addition, the Tuy River drainage basin, of approximately $6600 \mathrm{~km}^{2}$, covers an active industrial and agricultural area which also affects water quality (Jaffe et al. 1995).

Vanadium in Tivela mactroides was significantly higher in El Hatillo. This coastal area contains very extensive petroleum refining and transportation activities and is located near of the mouth of the Unare River, which flows along the one of the most important oil producing areas for Venezuela. Vanadium is typically associated to oil (Macías-Zamora et al. 1999; Agusa et al. 2004).

The mean concentrations of $\mathrm{Cd}$ and $\mathrm{Cr}$ in Crassostrea rhizophorae samples were significantly higher in Los Pozones. This region is one of the most important tourist (boats and jet skis) zones from Venezuela. Cd and Cr are typically associated to coatings (anti-corrosives), fossil fuel combustion, paints and pigments, and others industrial processes (Siegel 2002).

In contrast to the others elements with significant differences between sites, the difference in the mean concentrations of $\mathrm{Cu}$ and 
TABLE 3

Results of the one-way ANOVA of comparison between the two sampling times for metal concentrations

\begin{tabular}{|c|c|c|c|c|c|c|}
\hline $\begin{array}{l}\text { Sampling site } \\
\text { (organism) }\end{array}$ & $\mathrm{Cd}$ & $\mathrm{Cr}$ & $\mathrm{Cu}$ & $\mathrm{Ni}$ & V & $\mathrm{Zn}$ \\
\hline $\begin{array}{l}\text { Boca de Aroa } \\
\text { (T. mactroides) }\end{array}$ & 0.062 & 0.207 & 0.103 & 0.189 & 0.096 & 0.384 \\
\hline $\begin{array}{l}\text { Playa Chocolate } \\
\text { (T. mactroides) }\end{array}$ & 0.056 & 0.162 & 0.078 & 0.069 & 0.281 & 0.212 \\
\hline $\begin{array}{l}\text { El Hatillo } \\
\text { (T. mactroides) }\end{array}$ & 0.260 & 0.399 & 0.114 & 0.223 & 0.192 & 0.321 \\
\hline $\begin{array}{l}\text { Los Pozones } \\
\text { (C. rhizophorae) }\end{array}$ & 0.102 & 0.083 & 0.219 & 0.312 & - & 0.241 \\
\hline $\begin{array}{l}\text { Isla Buche } \\
\text { (C. rhizophorae) }\end{array}$ & 0.241 & 0.221 & 0.384 & 0.351 & - & 0.281 \\
\hline $\begin{array}{l}\text { Isla larga } \\
\text { (C. rhizophorae) }\end{array}$ & 0.401 & 0.198 & 0.219 & 0.254 & - & 0.199 \\
\hline $\begin{array}{l}\text { Isla Buche } \\
\text { (root-T. testudinum) }\end{array}$ & 0.111 & 0.088 & 0.241 & 0.165 & 0.243 & 0.058 \\
\hline $\begin{array}{l}\text { Isla Buche } \\
\text { (leaf-T. testudinum) }\end{array}$ & 0.201 & - & 0.301 & 0.098 & 0.261 & 0.079 \\
\hline $\begin{array}{l}\text { Pertigalete } \\
\text { (root-T. testudinum) }\end{array}$ & 0.251 & 0.185 & 0.152 & 0.231 & 0.152 & 0.066 \\
\hline $\begin{array}{l}\text { Pertigalete } \\
\text { (leaf-T. testudinum) }\end{array}$ & 0.304 & - & 0.212 & 0.259 & 0.185 & 0.126 \\
\hline $\begin{array}{l}\text { Isla Larga } \\
\text { (root-T. testudinum) }\end{array}$ & 0.326 & - & 0.367 & 0.127 & 0.208 & 0.201 \\
\hline $\begin{array}{l}\text { Isla Larga } \\
\text { (leaf-T. testudinum) }\end{array}$ & 0.264 & - & 0.184 & 0.210 & 0.136 & 0.084 \\
\hline
\end{tabular}

$\mathrm{Zn}$ in Tivela mactroides and $\mathrm{Cu}$ and $\mathrm{Ni}$ in Crassostrea rhizophorae, between the sampling sites where these bivalves were studied is negligible. In contrast to Zn, Ni bioaccumulation was examined in both species of bivalves. $\mathrm{Ni}$ concentrations found in C. rhizophorae at sampling sites are low compared to those obtained for T. mactroides. Some mussel species were found to be able to regulate the level of these biologically essential elements (Phillips 1985, Malinovskaya and Khristoforova 1997, Gunther et al. 1999), if the concentration in the aquatic environment does not exceed certain levels. As a consequence of this effect, a direct relationship between biologically essential element concentrations in the environments, on the one hand, and in the biomonitors, on the other hand, would be impossible to observe. 
TABLE 4

Mean concentration of metals in Tivela mactroides (standard deviation in brackets)

$\begin{array}{lcccccc}\text { Sampling site } & \begin{array}{c}\mathrm{Cd} \\ (\mu \mathrm{g} / \mathrm{g})\end{array} & \begin{array}{c}\mathrm{Cr} \\ (\mu \mathrm{g} / \mathrm{g})\end{array} & \begin{array}{c}\mathrm{Cu} \\ (\mu \mathrm{g} / \mathrm{g})\end{array} & \begin{array}{c}\mathrm{Ni} \\ (\mu \mathrm{g} / \mathrm{g})\end{array} & \begin{array}{c}\mathrm{V} \\ (\mu \mathrm{g} / \mathrm{g})\end{array} & \begin{array}{c}\mathrm{Zn} \\ (\mu \mathrm{g} / \mathrm{g})\end{array} \\ \text { Boca de Aroa } & 3.67(0.13) & 2.51(0.16) & 26.32(1.32) & 11.63(0.28) & 1.31(0.09) & 78.13(9.7) \\ \text { Playa Chocolate } & 4.39 *(0.28) & 3.67 *(0.17) & 26.20(1.35) & 13.26 *(0.33) & 1.21(0.07) & 87.89(7.3) \\ \text { El Hatillo } & 3.68(0.16) & 2.69(0.11) & 24.70(2.32) & 11.75(0.37) & 4.03^{*}(0.14) & 80.62(6.8)\end{array}$

* = mean values of elements with significant concentration differences between the sampling sites.

TABLE 5

Mean concentration of metals in Crassostrea rhizophorae (standard deviation in brackets)

$\begin{array}{lcccc}\text { Sampling site } & \begin{array}{c}\mathrm{Cd} \\ (\mu \mathrm{g} / \mathrm{g})\end{array} & \begin{array}{c}\mathrm{Cr} \\ (\mu \mathrm{g} / \mathrm{g})\end{array} & \begin{array}{c}\mathrm{Cu} \\ (\mu \mathrm{g} / \mathrm{g})\end{array} & \begin{array}{c}\mathrm{Ni} \\ (\mu \mathrm{g} / \mathrm{g})\end{array} \\ \text { Los Pozones } & 2.5^{*} & 2.4^{*} & 38 & 1.70 \\ & (0.6) & (0.5) & (4.73) & (0.38) \\ \text { Isla Buche } & 1.0 & 1.7 & 40 & 1.51 \\ & (0.1) & (0.3) & (4.67) & (0.09) \\ \text { Isla larga } & 1.6 & 1.8 & 35 & 1.49 \\ & (0.2) & (0.6) & (4.51) & (0.20)\end{array}$

$*$ = mean values of elements with significant concentration differences between the sampling sites.

TABLE 6

Mean concentration of metals in Thalassia testudinum (standard deviation in brackets)

\begin{tabular}{|c|c|c|c|c|c|c|c|}
\hline \multicolumn{2}{|c|}{ Sampling site } & Cd & $\mathrm{Cr}$ & $\mathrm{Cu}$ & $\mathrm{Ni}$ & $\mathrm{V}$ & $\mathrm{Zn}$ \\
\hline \multirow[t]{2}{*}{ Isla Buche } & root-rhizome & $1.52(0.53)$ & $2.14(0.30)$ & $5.86(0.48)$ & $4.62(2.53)$ & $6.51(0.25)$ & $25.11(5.93)$ \\
\hline & leaf & $1.79(0.89)$ & $<\mathrm{dl}$ & 3.80 (2.61) & $3.88(0.25)$ & $1.60(0.61)$ & $16.11(3.48)$ \\
\hline \multirow[t]{2}{*}{ Pertigalete } & root-rhizome & $1.49(0.24)$ & $1.81(0.48)$ & 4.73 (1.28) & $4.27(0.18)$ & $15.14 *(1.65)$ & 32.47 (4.68) \\
\hline & leaf & $1.6(0.37)$ & $<\mathrm{dl}$ & $6.01(1.62)$ & $4.83(2.34)$ & $2.20(0.81)$ & $14.07(2.14)$ \\
\hline \multirow[t]{2}{*}{ Isla Larga } & root-rhizome & $1.70(0.40)$ & $<\mathrm{dl}$ & $6.26(2.22)$ & 3.14 (1.17) & $4.49(0.15)$ & $32.58(7.02)$ \\
\hline & leaf & $1.62(0.26)$ & $<\mathrm{dl}$ & $5.41(0.52)$ & $2.80(1.44)$ & $1.09(0.92)$ & $12.31(3.10)$ \\
\hline
\end{tabular}

* = mean values of elements with significant concentration differences between the sampling sites.

$<\mathrm{dl}=$ below detection limit. 
At Pertigalete, the mean concentration of $\mathrm{V}$ in the seagrass root/rhizome tissue was significantly higher and the seagrass leaf tissue contained the highest values for this metal of the three sites where the seagrass was studied. This coastal area contains very extensive petroleum refining and transportation activities, and so, was not unexpected the higher value of V. Thus, the present results are consistent with the use of $\mathrm{V}$ as possible marker for oil transportation and exploitation activities. The values of the other metals studied did not show significant differences between leaf and root/ rhizome tissue.

T. testudinum is complex in trace metal distribution and appears to vary in concentration for each metal and morphological unit. Theses results suggest that if $T$. testudinum is to be used as a biomonitor, care must be taken to analyze the morphological units. The variability in trace metal content between the morphological units is highly dependent upon the metal in question. For example, $\mathrm{V}$ and $\mathrm{Zn}$ concentrations were found to be highest in root/ rhizome tissue by a factor of 2 to 7 compared to leaf tissues (Table 6).

The results of this study indicate that organisms considered selectively can accumulate certain elements. This selectivity is the most important criterion in choosing organisms as biomonitors (Duquesne et al. 2000). Sampling of Tivela mactroides, Crassostrea rhizophorae and Thalassia testudinum at sites along the Venezuelan coast revealed significant site-specific concentration differences for the elements Cd, Cr, Ni and V in Tivela mactroides tissue, $\mathrm{Cd}$ and $\mathrm{Cr}$ in Crassostrea rhizophorae tissue, and V in Thalassia testudinum tissue.

The mean concentrations in soft Tivela mactroides tissue found in Playa Chocolate are within the range of values determined in previous works for the same species of bivalve at the same sampling area (LaBrecque et al. 2004a, Alfonso et al. 2005). No known values have been reported for trace metals for Crassostrea rhizophorae and Thalassia testudinum in Venezuela.

\section{ACKNOWLEDGMENTS}

This work was jointly supported by of the FONACIT (Fondo Nacional de Ciencia, Tecnología e Innovación), grant G-2005000774. The authors also thank Jose Caceres and Carlos Bastidas for their assistance.

\section{RESUMEN}

Tivela mactroides y Crassostrea rhizophorae son dos especies de bivalvos abundantes a lo largo de la costa venezolana y de alta demanda local como mariscos. La hierba marina Thalassia testudinum, de interés en diferentes partes del mundo, es muy abundante en zonas costeras de Venezuela. Aquí informamos las concentraciones de $\mathrm{Cd}, \mathrm{Cr}, \mathrm{Cu}, \mathrm{Ni}, \mathrm{V}$ y Zn en muestras de partes blandas de Tivela mactroides y Crassostrea rhizophorae y de tejidos de Thalassia testudinum, recolectadas a lo largo de la costa venezolana. Estas concentraciones metálicas fueron determinadas utilizando espectrometría de emisión óptica con plasma inductivamente acoplado (ICP-OES). Los análisis estadísticos (ANDEVA de una vía) indicaron que las especies examinadas presentan características diferentes frente a la bioacumulación de metales y podrían ser utilizadas como potenciales indicadores para investigar la contaminación por metales trazas.

Palabras clave: bioacumulación metálica, Tivela mactroides, Crassostrea rhizophorae, Thalassia testudinum, bivalvos, hierba marina.

\section{REFERENCES}

Alfonso, J.A, J.A. Azocar, J.J. LaBrecque, Z. Benzo, P.R. Cordoves, M. Quintal, C.V. Gomez \& E. Marcano. 2005. Temporal and spatial variation of trace metals in clams Tivela mactroidea along the Venezuelan coast. Mar. Pollut. Bull. 50: 1723-1727.

Agusa, T., T. Kunito, S. Tanabe, M. Pourkazemi \& D.G. Aubrey. 2004. Concentrations of trace elements in muscle of sturgeons in the Caspian Sea. Mar. Pollut. Bull. 49: 789-800.

Catiski, V.A. \& P. Panayotidis. 1993. Copper, chromium and nickel in tissues of the Mediterranean seagrasses Posidonia oceanica and Cymodocea nodosa (Potamoetonaceae) from Greek coastal areas. Chemosphere 26: 963- 978.

Costantini, S., R. Giordano, L. Ciaralli \& E. Becaloni. 1991. Mercury, cadmium and lead evaluation in Posidonia oceanica and Codium tomentosum. Mar. Pollut. Bull. 22: 362-363. 
Duquesne, S., M. Riddle, R. Schulz \& M. Liess. 2000. Effect of contaminants in the Antarctic environment potential of the gammarid amphipod crustacean Paramorea walkeri as a biological indicator for Antarctic ecosystems based on toxicity and bioaccumulation of copper and cadmium. Aquat. Toxicol. 49: 131-143.

Fourqurean, J.W. \& Y. Cai. 2001. Arsenic and phosphorus in seagrass leaves from the Gulf of Mexico. Aquat. Bot. 71: 247-258.

Gunther, A.J., J.A. Davis, D.D. Hardin, J. Gold, D. Bell, J.R. Crick, G.M. Scelfo, J. Sericano \& M. Stephenson. 1999. Long-term bioaccumulation monitoring with transplanted bivalves in the San Francisco estuary. Mar. Pollut. Bull. 38: 170-181.

Jaffé, R., I. Leal, J. Alvarado, P. Gardinali \& J. Sericano. 1995. Pollution Effects of the Tuy River on the Central Venezuelan Coast: Anthropogenic Organic Compounds and Heavy Metals in Tivela mactroidea. Mar. Pollut. Bull. 30: 820-825.

Klumpp, D.H., R.K. Howard \& D.A. Pollard. 1989. Trophodynamics and nutritional ecology of seagrass communities, p. 394-457. In D.H. Klumpp, R.K. Howard \& D.A. Pollard (eds.). Biology of seagrasses. Elservier, Amsterdam, Amsterdam, Holland.

LaBrecque, J.J., Z. Benzo, J.A. Alfonso, P.R. Cordoves, M. Quintal, C.V. Gomez \& E. Marcano. 2004a. The concentrations of selected trace elements in clams Tivela mactroidea along the Venezuelan coast in the state of Miranda. and Commercial Clam Meats from the State of Miranda. Mar. Pollut. Bull. 49: 659-667.

LaBrecque, J.J., Z. Benzo, J.A. Alfonso, P.R. Cordoves, M. Quintal, C.V. Gomez \& E. Marcano. 2004b. The Determination of Selected Trace Elements in Raw Clams and Commercial Clam Meats from the State of Miranda (Venezuela) employing ICP-OES, GF-AAS and WD-XRF. At. Spectrosc. 25: 112-124.

Ledent, G., M.A. Mateo, M. Warnau, A. Temara, J. Romero \& P.H. Dubois. 1995. Element losses following distilled water rinsing of leaves of the seagrass Posidonia oceanica (L) Delile. Aquat. Bot. 52: 229-235.

Liang, L.N., B. He, G.B. Jiang, D.Y. Chen \& Z.W. Yao. 2004. Evaluation of mollusks as biomonitors to investigate heavy metal contaminations along the Chinese Bohai Sea. Sci. Total Environ. 324: 105-113.

Macías-Zamora, J.V., J.A. Villaescusa-Celaya, A. MuñozBarbosa \& G. Gold-Bouchot. 1999. Trace metals in sediment cores from the Campeche shelf, Gulf of Mexico. Environ. Pollut. 104: 69-77.

Malinovskaya, T.M. \& N.K. Khristoforova. 1997. Characterization of coastal waters of the south Kuril Islands by the trace element content of indicatory organisms. Russ. J. Mar. Biol. 23: 212-218.

Phillips, D.J.H. 1985. Trace metals in bivalve molluscs from Thailand. Mar. Environ. Res. 15: 215-234.

Pulich, W.M. 1980. Heavy metal accumulation by selected Holodule wrightii Asch. Populations in the Corpus Christi bay area. Contrib. Mar. Sci. 23: 90-100.

Rainbow, P.S., M. Wolowicz, W. Fialkowski, B.D. Smith \& A. Sokolowski. 2000. Biomonitoring of trace metals in the Gulf of Gdansk, using mussels (Mytilus trossulus) and barnacles (Balanus improvisus). Water Res. 6: 1823-1829.

Ruelas-Inzunza, J.R. \& F. Páez-Ozuna. 2000. Comparative bioavailability of trace metals using filter-feeder organisms in a subtropical coastal environment (Southeast Gulf of California). Environ. Pollut. 107: 437-444.

Siegel, F.R. 2002. Sources and origins of the metals, p. 15-44. In F.R. Siegel (ed.). Environmental Geochemistry of Potentially Toxic Metals. SpringerVerlag, Berlin, Berlin, Germany.

Silva, C.A., B.D. Smith \& P.S. Rainbow. 2006. Comparative biomonitors of coastal trace metal contamination in tropical South America (N. Brazil). Mar. Environ. Res. 61: 439-455.

Whelan III, T., J. Espinoza, X. Villareal \& M. CottaGoma. 2005. Trace metal partitioning in Thalassia testudinum and sediments in the Lower Laguna Madre, Texas. Environ. International 31: 15-24.

Zieman, J.C. 1982. The ecology of the seagrasses of South Florida: a community profile. Fish and Wildlife Service, Office of Biological Services [FWS/OBS 82/25], Washington, DC, USA. 320 p. 